\title{
Analysis of Patients Presenting to a Pediatric Emergency Department with Acute Limping
}

\author{
Çocuk Acil Ünitesine Ani Başlayan Aksama Yakınması ile Getirilen Hastaların Analizi
}

\author{
Sabiha Şahin \\ Eskişehir Osmangazi University Faculty of Medicine, Department of Pediatric Emergency Medicine, Eskişehir, Turkey
}

\section{Abstract}

Introduction: Limping is a common presenting complaint to a pediatric emergency department among children. The differential diagnosis of acute limp includes transient synovitis, trauma, infections, neoplasia, and congenital neuromuscular and developmental disorders. We aimed to evaluate patients presenting with acute limp to our pediatric emergency department and to analyze the clinical characteristics of the disease. In addition, we aimed to investigate the value of several laboratory parameters in early identification of septic and aseptic conditions.

Methods: We retrospectively analyzed children under 18 years of age who were admitted to our emergency department with acute limping in a two-year period. Patients with any chronic diseases, any history of trauma, coagulopathy (as documented by blood clotting tests) and any history of intramuscular injections within the previous week were excluded. The patients' complete blood count, erythrocyte sedimentation rate (ESR), C-reactive protein (CRP) levels, plain pelvic radiographs and ultrasonography reports were evaluated. The patients were classified as septic or aseptic according to their white blood cells (WBC), CRP and ESR values. Totally 120 patients were included in the study. The upper limit for WBC, ESR and CRP was accepted as 9000 cells $/ \mathrm{mm}^{3}, 20 \mathrm{~mm} / \mathrm{h}$ and $0.8 \mathrm{mg} / \mathrm{dL}$, respectively. Results: Of the total of 86 patients in the aseptic group, 81 had normal WBC, ESR and CRP levels and were diagnosed with transient synovitis, 2 female patients received the diagnosis of slipped upper femoral epiphysis, and 3 patients were diagnosed with Legg-Calvé-Perthes disease during clinical follow-up. The remaining 34 patients with high ESR, WBC and CRP levels were included in the septic group in whom the following diagnoses were established during the follow-up: septic arthritis $(n=12)$, Familial Mediterranean Fever $(n=4)$, juvenile rheumatoid arthritis $(n=4)$, GuillainBarré syndrome $(n=3)$, osteomyelitis $(n=3)$, acute rheumatic fever $(n=3)$, spondyloarthritis $(n=3)$ and Ewing sarcoma $(n=2)$. There was a significant difference in CRP and WBC values between the septic and the aseptic groups, but no significant difference was found in ESR values.

Conclusion: Acute atraumatic limp is a commonly encountered condition in children presenting to pediatric emergency departments. Transient synovitis is the most common cause of limping. CRP and WBC are two sensitive markers for diagnosing infectious and malignant etiology in this group of children.

Keywords: Child, limping, acute

\section{Öz}

Amaç: Aksama çocuklarda yaygın bir acil servise başvuru nedenidir. Normal yürüyüş paternine göre asimetrik bir tarz oluşması şeklinde tanımlanabilir. Ayırıcı tanısında geçici sinovit, travma, enfeksiyon, tümör veya enflamatuvar nedenler, doğuştan nöromusküler hastalıklar veya gelişimsel bozukluklar düşünülmelidir. Bu çalışmada çocuk acil servisine ani gelişen aksama ile başvuran hastaların sonuçlarını değerlendirmeyi ve bulgularımıza göre hastaların tanı ve takip açısından bazı ipuçları elde etmeyi planlayıp, septik veya aseptik nedenlerin erken tanısında laboratuvar değerlerinin faydasını değerlendirmeyi amaçladık.

Yöntemler: Son 2 yıllık sürede ani başlayan aksama tanısı olan hastalar geriye dönük olarak değerlendirildi. Süreğen hastalık, travma, hematolojik koagülopatisi olanlar ve son bir hafta içinde kasiçi enjeksiyon yapılmış olan hastalar çalışma kapsamına alınmadı. Çalışmaya dahil olanlar beyaz küre (WBC), eritrosit sedimentasyon hızı (ESR), C-reaktif protein (CRP), düz radyografi ve pelvik ultrasonografi (USG) sonuçlarına göre septik ve aseptik olarak iki gruba ayrıldı. Toplamda 120 hasta çalışma grubuna alındı. Referans değerleri WBC, ESR ve CRP için $9000 \mathrm{~K} / \mathrm{mm}^{3}, 20 \mathrm{~mm} /$ saat ve 0,8 $\mathrm{mg} / \mathrm{dL}$, olarak kabul edildi.

Bulgular: Seksen altı hastanın WBC, ESR ve CRP düzeyleri normaldi, 81 çocuk geçici sinovit, 2'si femur başı epifiz kayması ve 3'ü LeggCalvé-Perthess tanılarını almıştı ve aseptik grup olarak tanımlandı. WBC, ESR ve CRP düzeyleri yüksek olan 34 hasta ise septik grup olarak tanımlandı ve septik artrit $(n=12)$, osteomiyelit $(n=3)$, juvenil romatoid artrit $(n=4)$, Ailevi Akdeniz Ateşi $(n=4)$, akut romatizmal ateş $(n=3)$, spondiloartrit $(n=3)$, Guillian Barre sendromu $(n=3)$ ve Ewing sarkomu $(n=2)$ tanılarını almışlardı. Septik ve aseptik gruplar arasında CRP ve WBC düzeyleri açısından anlamlı farklıık vardı. ESR değerleri gruplar arasında anlamlı farklılık görülmedi.

Sonuç: Travmatik olmayan akut aksama çocuk acil servise başvuran çocuklarda yaygın bir sorundur. Geçici sinovit en yaygın aksama nedenidir. CRP ve WBC enfeksiyöz ve malign hastalıkların tanısı için duyarlı ölçümlerdir.

Anahtar Kelimeler: Çocuk, aksama, akut

Address for Correspondence/Yazışma Adresi: Sabiha Şahin MD, Eskişehir Osmangazi University Faculty of Medicine, Department of Pediatric Emergency Medicine, Eskişehir, Turkey E-mail: sabiha.sahin@mynet.com ORCID ID: orcid.org/0000-0002-0655-4536

Received/Geliş Tarihi: 03.03.2017 Accepted/Kabul Tarihi: 31.05.2017

${ }^{\circ}$ Copyright 2017 by Society of Pediatric Emergency and Intensive Care Medicine

Journal of Pediatric Emergency and Pediatric Intensive Care published by Galenos Yayınevi. 


\section{Introduction}

Acute atraumatic limp is a common cause of presentation to pediatric emergency department (PED) among children, with an incidence rate of 1.8 in 1000, a male-to-female ratio of 1.7:1 and a median age of 4.4 years, as has been previously reported. ' Children are frequently brought to PED for limping without a clear history of a previous injury. Limping is defined as an asymmetry or a disruption of the normal gait pattern. Acute $\operatorname{limp}$ in a child without any complaints should be investigated for various etiologies, including trauma coming in the first place. Recent intramuscular injections may also be the cause. In many cases, limp is temporary and has a self-limiting course. Nevertheless, in some cases, it may also occur as a manifestation of a life-threatening condition. ${ }^{2}$ The differential diagnosis of acute limp should include trauma, infections, neurological diseases, neoplasia, and congenital neuromuscular and developmental disorders. In this study, we aimed to evaluate patients presenting with acute limp to our PED and to analyze the clinical characteristics of the disease. Additionally, we aimed to investigate the value of several laboratory parameters in early identification of several etiological conditions with significant morbidity such as septic arthritis and osteomyelitis.

\section{Materials and Methods}

This retrospective study was conducted at our PED between January 2014 and December 2016. Children who presented with acute limp and who had complete and reliable medical records for reviewing were included in the study. Patients with any chronic diseases, coagulopathy (as documented by blood clotting tests), any history of intramuscular injections within the previous week and any history of antibiotics and analgesic usage within the past two weeks were excluded from the study. A total of 120 patients were included in our work. Patients' complete blood count, erythrocyte sedimentation rate (ESR), C-reactive protein (CRP) levels, plain pelvic radiographs and ultrasonography (USG) reports were evaluated. USG examinations were performed by an experienced radiologist. A definitive diagnosis of septic arthritis was established after bacteriological evaluation of synovial fluid aspirated by an orthopedist. The patients were classified into septic or aseptic groups according to their white blood cells (WBC), CRP and ESR results. According to the reference values of our biochemistry laboratory, the upper limit for WBC, ESR and CRP was accepted as 9000 cells/ $\mathrm{mm}^{3}, 20 \mathrm{~mm} / \mathrm{hr}$ and $0.8 \mathrm{mg} / \mathrm{dL}$, respectively. The study was approved by the Eskişehir Clinical Research Ethical Committee, approval number: EsKAEK 64/09.

\section{Statistical Analysis}

SPSS 17.0 software package was used for statistical analysis. Descriptive data were expressed as frequency, percentage, mean and standard deviation. A receiver operating characteristic curve (ROC curve) analysis was recruited to determine the cut-off points for the evaluated diagnostic tests. Sensitivity, specificity, positive predictive values and negative predictive values for the established cut-off thresholds were calculated accordingly. The results were assessed at 95\% confidence interval; statistical significance level was set at $p<0.05$, and $p$ values $<0.01$ and $<0.001$ were accepted as indicators for high significance.

\section{Results}

The mean age of the patients was $4.13 \pm 63$ years (range: 19 months- 17 years). $48.33 \%$ of the subjects were female. Of the total of 86 patients in the aseptic group, 81 had normal WBC, ESR and CRP levels and were diagnosed with transient synovitis (TS), 2 female patients with slipped upper femoral epiphysis (SUFE), and 3 patients were diagnosed with LeggCalvé-Perthes disease during clinical follow-up. The age of these aseptic group patients ranged from 19 months to 6 years. Additionally, of the patients in the aseptic group, $16 \mathrm{had}$ otitis, 5 had urinary infection and 60 had not any infection foci. Appropriate antibiotic medication and ibuprofen were prescribed for these 21 children with infection; whereas, the remaining 60 patients without infection were given only ibuprofen. No additional pathological finding was determined in the aseptic group, and limping resolved within 3 days.

In the remaining 34 patients with high ESR, WBC and CRP levels, who were included in the septic group, the following diagnoses were established during the follow-up: septic arthritis $(n=12)$, Familial Mediterranean Fever (FMF) $(n=4)$, juvenile rheumatoid arthritis (JRA) $(n=4)$, Guillain-Barre syndrome $(n=3)$, osteomyelitis $(n=3)$, acute rheumatic fever $(n=3)$, spondyloarthritis $(n=3)$ and Ewing sarcoma $(n=2)$. The age of these patients ranged from 6 to 17 years (Table 1).

WBC was found to be statistically significant for discrimination between septic and aseptic groups $(p=0.002<0.001)$ In the septic group, the optimum cut-off value determined as 9670 cells $/ \mathrm{mm}^{3}$ indicated that sensitivity was $78.6 \%$ and specificity was $41.7 \%$ as shown in (Table 1, Figure 1).

CRP was found to be statistically significant for discrimination between septic and aseptic groups $(p=0.045<0.001)$. In the septic group, the optimum cut-off value was determined as $3.285 \mathrm{mg} / \mathrm{dL}$. At this point, the sensitivity was $80.0 \%$ and the specificity was $95.6 \%$ as shown in (Table 1, Figure 2 ).

Septic groups had no significant effect on ESR levels ( $p=0.172$ $>0.05$ ). Therefore, no cut-off value could be measured (Table 1, Figure 3). 
Table 1. Comparison of septic group with aseptic group

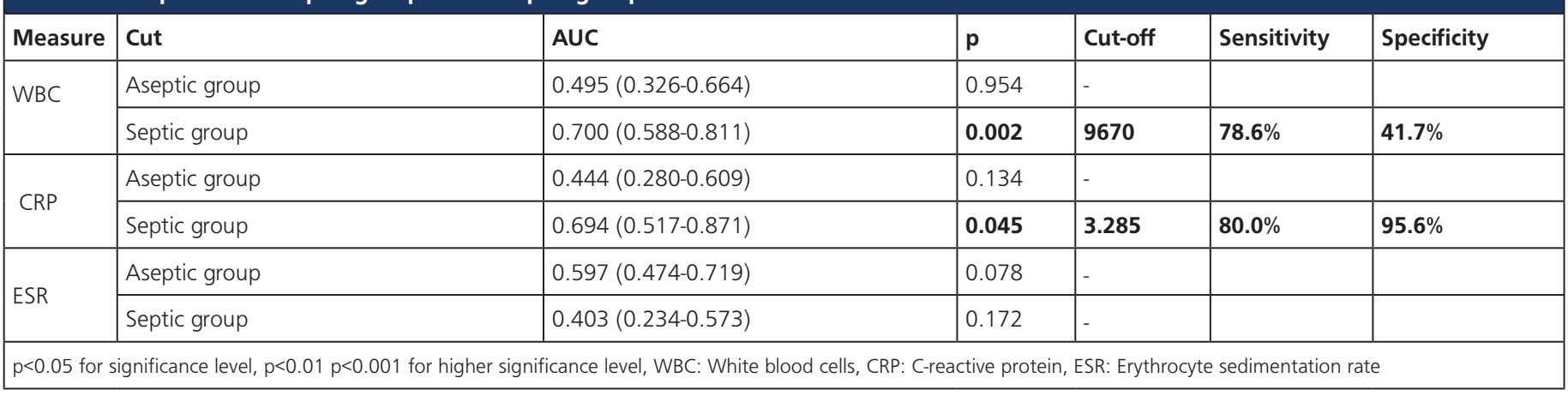

\section{Discussion}

In the differential diagnosis of acute limping, TS, trauma, infection, neoplasia and inflammatory, congenital, neuromuscular or developmental disorders should be distinguished. In a patient with knee or thigh pain, the underlying hip condition should be considered. The age of the patient may help to further identify the differential diagnosis, and it is known that some disease conditions are age specific. Limp may be due to serious and life-threatening conditions. Therefore, the clinician must thoroughly evaluate the spine, pelvis and lower extremities for a possible pathology. ${ }^{1,2}$

TS, a benign self-limiting condition, which is usually treated with bed rest and anti-inflammatory analgesic drugs, is the most common cause of acute atraumatic limp in children. ${ }^{3-5}$ Occasionally, a limp in a child can be an early manifestation of a serious condition such as septic arthritis or neoplasm, resulting in long-term complications if the diagnosis is delayed.6-9 Inflammatory serum parameters including ESR, CRP and WBC counts may be slightly elevated in TS; although, raised inflammatory markers are also strong predictors of more severe conditions such as septic arthritis. ${ }^{9}$

Differentiating septic arthritis from TS is a usual practice in PED. A study by Kocher et al. ${ }^{10}$ evaluated the utility of these above-mentioned parameters to distinguish these two clinical conditions. These were a temperature higher than $38.5^{\circ} \mathrm{C}$, ESR above $40 \mathrm{~mm} / \mathrm{h}$ and serum WBC higher than 12000 cells/ $\mathrm{mm}^{3}$. The simplified algorithm is optimally modeled to the original data set. Despite this, they may be useful provided they are applied with caution. ${ }^{10-12}$

According to our results, ESR was higher in the septic group but the difference was not statistically significant when compared with the aseptic group, which may be attributable to our limited number of cases. According to the previous reports, if an infection is being considered after a detailed history and physical examination, laboratory tests for WBC, ESR and CRP should be performed. ${ }^{10}$ In these cases, CRP levels become elevated earlier than ESR and are considered to be more sensitive for diagnosing an infectious process.
Additionally, recording the baseline levels of ESR and CRP will be useful in monitoring the clinical responses to the antibiotic treatment. It was reported that the septic arthiritis was correctly identified in $97 \%$ of the limp-treated patients when the ESR was higher than 20 and the body temperature was above $37.5^{\circ} \mathrm{C}\left(99.5^{\circ} \mathrm{F}\right) .{ }^{10}$ Therefore, patients with high WBC, ESR and CRP values should be hospitalized and closely monitored. No definitive test has been described for diagnosis of TS, and further studies are warranted.

Elevated inflammatory blood markers, such as ESR, CRP and WBC counts, are strong predictors of severe conditions such as septic arthritis.9,10 In our study, WBC count was found to be a statistically significant marker for discriminating between the septic and aseptic groups ( $p=0.002)$. In the septic group, the optimum cut-off threshold for WBC count was calculated to be $9670 / \mathrm{mm}^{3}$, which gave a sensitivity of $78.6 \%$ and specificity of $41.7 \%$. CRP was also found to be statistically useful for the same discrimination purposes between the two groups ( $p=0.045$ ). In the septic group, the optimum cut-off threshold for CRP was determined to be $3.285 \mathrm{mg} / \mathrm{dL}$. Using this cut-off point, the sensitivity was $80.0 \%$ and the specificity was $95.6 \%$. ESR levels, on the other hand, did not reveal any significant discriminative power between the septic and the aseptic groups $(p=0.172)$.

An ultrasound scan of the hip can readily demonstrate any presence of fluid inside the joint capsule. However, it cannot reliably distinguish septic arthritis from TS. In order to rule out septic arthritis, a needle aspiration of the synovial fluid should be performed under USG guidance. In TS, the synovial fluid is usually clear. On the other hand, in septic arthritis, the fluid is generally purulent-appearing and should be sent for bacterial culture and antibiotic sensitivity testing. ${ }^{11}$ USG examination results of 81 patients were suggestive of TS in our study. Twelve patients were diagnosed with septic arthritis based on the laboratory results for the aspirated synovial fluid samples. In a study by Fischer and Beattie ${ }^{1}$ TS was diagnosed in $39.5 \%$ of a total of 243 patients with a mean age of 4.35 years who presented with atraumatic limping to PED. In that 


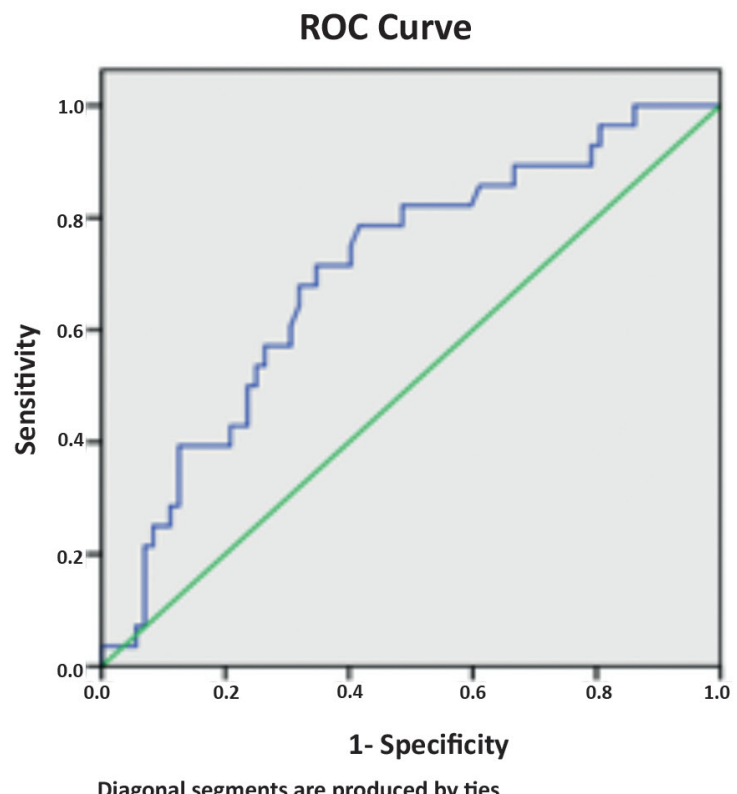

Diagonal segments are produced by ties

Figure 1. White blood cells levels in the septic group

\section{ROC Curve}

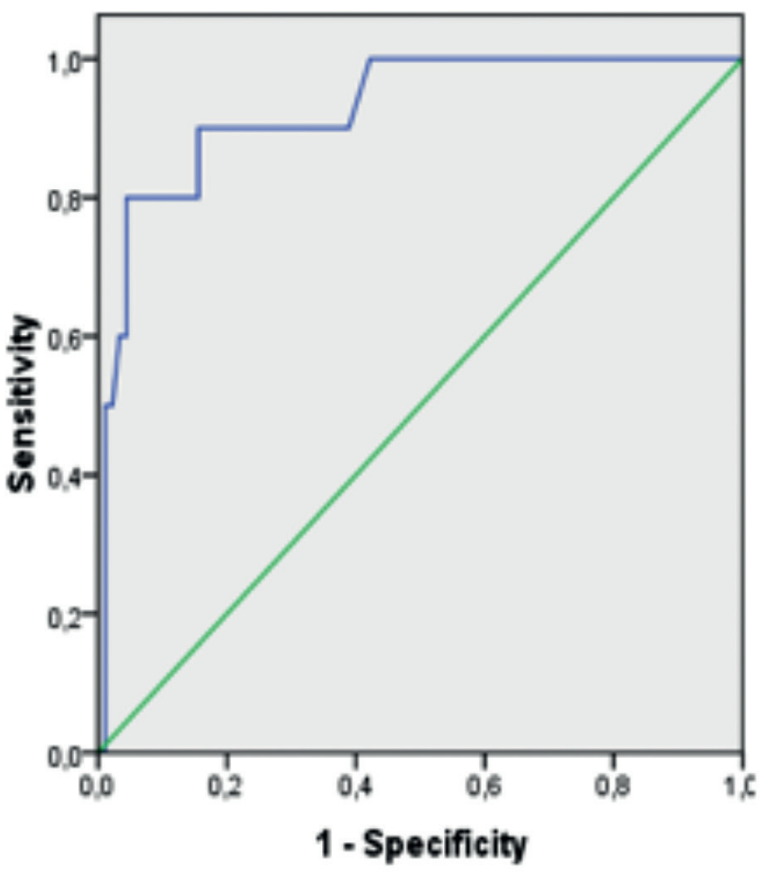

Diagonal segments are produced by ties.

Figure 2. C-reactive protein levels in the septic group

study, TS was reported to be more common in boys than in girls, consistent with our results. In another study, among children with atraumatic limping, the prevailing etiologies with regard to the age groups were reported to be as follows:
ROC Curve

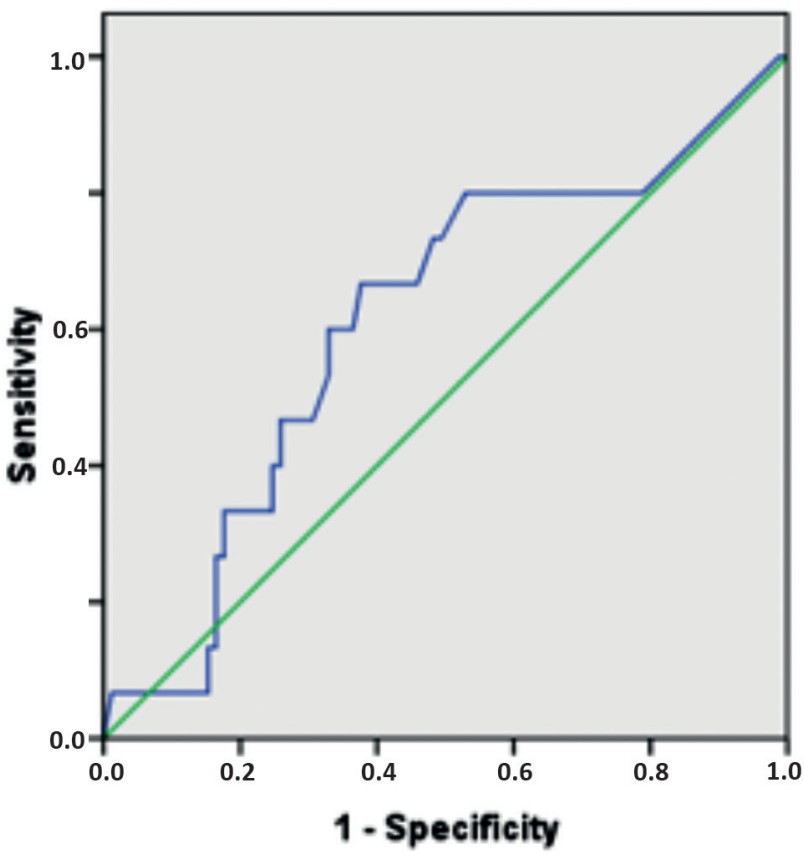

Diagonal segments are produced by ties.

Figure 3. Erythrocyte sedimentation rate levels in the septic group

developmental dysplasia (dislocation) of the hip and Toddler fracture - between 1 and 3 years of age; TS, Perthes disease and JRA - between 1 and 10 years; and SUFE, avascular femoral head necrosis and gonococcal septicemia - between 11 and 16 years. ${ }^{11}$ The rate of TS in our study was $67.5 \%$ with an age range of from 19 months old to 6 years.

Numerous studies have emphasized the importance of a detailed history taking and physical examination. ${ }^{12-15}$ Careful evaluation of the pattern, onset and duration of the pain may provide information about its origin. Mechanical pain (exacerbating with activities and relieving with rest) may be suggestive of a herniated lumbar disk or spondylolisthesis. A constant and progressive pain causing night awakening and not relieving by resting should raise concerns about a more serious condition (e.g., malignancy or infection). Growth pains are frequently bilateral and start at nights, and patients are usually comfortable during the day. Asymmetric abduction at the supine position should suggest irritation of the hip joint. FABER test (also referred to as Patrick's test) is used to examine the sacroiliac joint. ${ }^{16-19}$

Once a spinal etiology of limping is suspected, plain radiographs of the spine as well as of the pelvic area should be taken, in that, pelvic, sacral or sacroiliac lesions may mimic spinal disorders. With a careful examination, evidence of scoliosis, vertebral scalloping, vertebral pedicle destruction, 
intervertebral space narrowing, end-plate erosions, vertebral collapse, spondylolisthesis, etc. should be looked for. Plain films of the areas in question should be the initial radiographic studies to be ordered. If the radiographs are nondiagnostic or unclear despite a strong clinical suspicion, further imaging studies are indicated according to the suspected disorder. ${ }^{20,21}$ In patients with a history and/or physical examination consistent with hip infection, USG is useful in documenting any synovial fluid collections. In a previous study, USG has been found to be more sensitive for this purpose than plain films. In that study, USG detected synovial effusion in two-thirds of a series of 500 children with normal plain radiographs. ${ }^{21}$ USG is noninvasive, but its diagnostic performance is highly operator-dependent. It is also useful in identifying fluid collections within the soft tissues, which may be suggestive of a soft tissue abscess. ${ }^{22}$ It is recommended that plain radiographs should be used to exclude bone fractures. ${ }^{23}$ USG has been recommended in children under 8 years old. The cases younger than 8 years old who show normal CRP and ESR levels, normal WBC counts and who have their body temperatures not higher than 37.5 ${ }^{\circ} \mathrm{C}$ should be considered as TS and their control visits may be scheduled within 5 days. CRP is a better negative predictor than a positive predictor of an infection. Indeed, a CRP value of $<1.0 \mathrm{mg} / \mathrm{dL}$ means that the probability that the patient does not have septic arthritis is $87 \% .{ }^{24}$ TS may be of a viral or allergic origin and its recurrence rate is about $2 \%$. In patients older than 8 years old, pelvic USG is needed to exclude the Perthes disease and SUFE. ${ }^{25}$ A diagnosis of SUFE should not be overlooked in children between 10 and 16 years of age with a sudden onset of acute limping. This condition can be easily diagnosed by a plain radiography. Early diagnosis is of paramount importance for SUFE in that, early detected cases can be successfully treated without any sequelae.

\section{Conclusion}

Various pathologies, depending on the age of the patient, may underline acute limping in children. Between 3 and 10 years of age, TS of the hip and Legg-Calvé-Perthes disease constitute the most common etiologies, however, infection, inflammation and focal bony lesions must also be considered. In children older than 10 years old, a slipped capital femoral epiphysis should also be considered. A detailed history taking and systemic physical examination, as well as an appropriate laboratory investigation, are necessary for an accurate diagnosis. Our results suggest that laboratory workup for WBC and CRP, and pelvic USG are important for an initial evaluation of the cases. A workup algorithm is yet to be established by further studies. ${ }^{26,27}$

\section{Ethics}

Ethics Committee Approval: The study was approved by the Eskişehir Clinical Research Ethical Committee, approval number: EsKAEK 64/09.
Informed Consent: Retrospective study.

Peer-review: Externally and Internally peer-reviewed.

Financial Disclosure: The author declared that this study received no financial support.

\section{References}

1. Fischer SU, Beattie TF. The limping child: epidemiology, assessment and outcome. J Bone Joint Surg Br. 1999;81:1029-34.

2. Asche SS, van Rijn RM, Bessems JH, Krul M, Bierma-Zeinstra SM. What is the clinical course of transient synovitis in children: a systematic review of the literature. Chiropr Man Therap. 2013;21:39.

3. Ferey S, Merzoug V. The acutely limping child. J Radiol. 2011;92:495505.

4. Kermond S, Fink M, Graham K, Carlin JB, Barnett P. A randomized clinical trial: should the child with transient synovitis of the hip be treated with nonsteroidal anti-inflammatory drugs? Ann Emerg Med. 2002;40:294-9.

5. Dan M. Septic arthritis in young infants: clinical and microbiologic correlations and therapeutic implications. Rev Infect Dis. 1984;6:14755.

6. Petersen S, Knudsen FU, Andersen EA, Egeblad M. Acute haematogenous osteomyelitis and septic arthritis in childhood. A 10-year review and follow-up. Acta Orthop Scand. 1980;51:451-7.

7. Skinner J, Glancy S, Beattie TF, Hendry GM.I "Transient synovitis: is there a need to aspirate hip joint effusions?". Eur J Emerg Med. 2002;9:15-8

8. Del Beccaro MA, Champoux AN, Bockers T, Mendelman PM. Septic arthritis versus transient synovitis of the hip: the value of screening laboratory tests. Ann Emerg Med. 1992;21:1418-22.

9. Shah SS. Abnormal gait in a child with fever: diagnosing septic arthritis of the hip. Pediatr Emerg Care. 2005;21:336-4.

10. Kocher MS, Mandiga R, Zurakowski D, Barnewolt C, Kasser JR. Validation of a clinical prediction rule for the differentiation between septic arthritis and transient synovitis of the hip in children. J Bone Joint Surgery Am. 2004;86:1629-35.

11. Mattick A, Turner A, Ferguson J, Beattie T, Sharp J. Seven year follow-up of children presenting to the accident and emergency department with irritable hip. J Accid Emerg Med. 1999;16;345-7.

12. Blatt SD, Rosenthal BM, Barnhart DC. Diagnostic utility of lower extremity radiographs of young children with gait disturbances. Pediatrics 1991;87:138-40.

13. Ryan DD. Differentiating Transient Synovitis of the Hip from More Urgent Conditions. Pediatr Ann. 2016;45:6:209-13.

14. Singhal R, Perry DC, Khan FN, Chon D, Stevenson HL, et al. The use of CRP within a clinical prediction algorithm for the differentiation of septic arthritis and transient synovitis in children. Bone Joint Surg Br. 2011;93:1556-61.

15. Moder KG, Hunder GG. Examination of the joints. In: Kelley WN, Harris ED, Ruddy S (eds). Textbook of Rheumatology. 5th, WB Saunders, Philadelphia, 1997:364. 
16. Slipman CW, Sterenfeld EB, Chou LH, Herzog R, Vresilovic E. The predictive value of provocative sacroiliac joint stress maneuvers in the diagnosis of sacroiliac joint syndrome. Arch Phys Med Rehabil. 1998;79:288-92.

17. Kermond S, Fink M, Graham K, Carlin JB, Barnett P. A randomized clinical trial: should the child with transient synovitis of the hip be treated with nonsteroidal anti-inflammatory drugs? Ann Emerg Med. 2002;40:294-9.

18. Oudjhane K, Newman B, Oh KS, Young LW, Girdany BR. Occult fractures in preschool children. J Trauma. 1998;28:858-60.

19. Alexander JE, Seibert JJ, Glasier CM, Williamson SL, Aronson J, et al. High resolution hip ultrasound in the limping child. J Clin Ultrasound. 1989;17:19-24.

20. Miralles M, Gonzalez G, Pulpeiro JR, Millán JM, Gordillo I, et al. Sonography of the painful hip in children: 500 consecutive cases. AJR Am J Roentgenol. 1989;152:579-82.

21. Rosenborg $M$, Mortensson W. The validity of radiographic assessment of childhood transient synovitis of the hip. Acta Radiol Diagn (Stockh). 1986;27:85-9.
22. Garrison J, Nguyen M, Marin JR. Emergency Department Point-ofCare Hip Ultrasound and Its Role in the Diagnosis of Septic Hip Arthritis: A Case Report. Pediatric Emergency Care. 2016;32:555-7.

23. Flynn JM, Widmann RF. The limping child: evaluation and diagnosis. J Am Acad Orthop Surg. 2001;9:89-98.

24. Levine MJ, McGuire KJ, McGowan KL, Flynn JM. Assessment of the test characteristics of C-reactive protein for septic arthritis in children. J Pediatr Orthop. 2003;23373-7.

25. Rubin S, Ramachandran M. Femoro-Acetabular Impingement in Children. Paediatric Orthopaedics. 2016;25:83-9.

26. Pääkkönen $M$, Kallio $M J$, Kallio PE, Peltola $H$, et al. Sensitivity of erythrocyte sedimentation rate and C-reactive protein in childhood bone and joint infections. Clin Orthop Relat Res. 2010;468:861-6.

27. Cavkaytar O, Düzova A, Tekşam O, Karabulut E, Derman O, et al. Final diagnosis of children and adolescents with musculoskeletal complaints. Minerva Pediatr. 2017;69:50-8. 